\section{SOI: 1.1/TAS DOI: 10.15863/TAS International Scientific Journal Theoretical \& Applied Science}

p-ISSN: 2308-4944 (print)

e-ISSN: 2409-0085 (online)

Year: 2016

Issue: 4

Volume: 36

Published: 30.04 .2016

http://T-Science.org

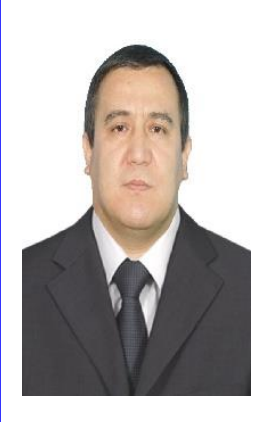

Abror Niyatkobilovich Achilov independent competitor of department

"Accounting"

Tashkent State University of Economics

Uzbekistan

e-mail: g7777@mail.ru

Phone: +998905619205

SECTION 31. Economic research, finance, innovation, risk management.

\title{
ACCOUNTING FOR INVENTORY AT THE ENTERPRISES OF THE REPUBLIC OF UZBEKISTAN
}

Abstract: The article deals with the accounting for inventories on the example of the chemical industry. The emphasis is on the basic principles of accounting inventories economic entity.

Key words: accounting, inventory, LIFO, FIFO, AVECO, cash.

Language: English

Citation: Achilov AN (2016) ACCOUNTING FOR INVENTORY AT THE ENTERPRISES OF THE REPUBLIC OF UZBEKISTAN. ISJ Theoretical \& Applied Science, 04 (36): 181-183.

Soi: http://s-o-i.org/1.1/TAS-04-36-30

Doi: crossef http://dx.doi.org/10.15863/TAS.2016.04.36.30

Modern economic mechanism of activity of the enterprises of the chemical industry of Uzbekistan provides for expanding the boundaries of independence while increasing accountability for results, fulfillment of obligations to consumers, establishing a direct level of the collective income, depending on the effectiveness of its work.

For effective use of inventory resources plays an important role accounting inventories. Inventories are an integral part of the company's assets.

Assets - are the resources and assets controlled by the economic entity as a result held in the past transactions and events. Assets are resources that can provide some economic benefit in the future, otherwise they are not more than the potential losses or ongoing operating costs, and therefore it should not be recognized as assets. The future economic benefit is the ultimate in receipt of cash or cash equivalents, or the ability to replace (and save) money. The future economic benefits embodied in the asset could be realized (received) in various ways. Assets can be used alone or in combination with other assets in the production of goods, works and services to be sold now for money or exchanged goods for other assets. Use of assets in production the most common way is to extract the benefits, if the goods are manufactured on a sustainable purchasing power market. Assets can be sold for money or exchanged for other assets for the benefit of the seller. Assets can be directed to repay obligations to creditors or owners, distributed among the shareholders. The structure of assets is represented by property in material form, as well as intangible assets related to legal rights. Assets are usually purchased for money; is the most common, though by no means the only way to purchase the assets. Consequently, between the emerging enterprise costs and assets coming a close, but not an absolute link. Costs incurred do not mean the acquisition of the asset, we need reasonable assurance that the economic benefits from it, otherwise such costs should be attributed to the costs. Costs are a means of generating income, but relate to assets only in the event that the receipt of income is transferred to future periods. On the other hand, the absence of costs does not prevent the emergence of an asset in certain circumstances, for example, upon receipt of the property without compensation. The assets are initially measured only by the accomplished transactions; intention to acquire those or other assets may not be sufficient grounds for taking them into account. To asset has been recognized in the balance sheet, it should be monitored and the cost now. Thus, the assets - is the economic resources controlled by the entity that should be profitable in the future.

The company is free to decide how to determine the cost of material resources, written off in production (for implementation): - on the FIFO (first in the production costs are written off the value of stocks purchased or produced first); - On an average cost basis, or "avec" (the cost of each item is determined from the weighted average cost of similar items at the beginning of the period and the cost of similar items purchased or produced during the period). The average cost of the same can be calculated in two ways: - either on a periodic basis, 
for example at the end of each reporting period (example, month) - or in the course of each additional delivery. If an entity applies the weighted average cost method, one of the two above methods should be reflected in its accounting policies. Along with the methods FIFO and average cost method of valuation provided for the use of written off inventory cost of each unit, ie, if you are using inventories for specific purposes, or if these stocks can not be replaced in the usual manner to each other, their evaluation can be performed by each unit of cost, for example, precious metals, stones, etc.

It reserves include assets in the form of raw materials and materials for use in the production of goods and services, or intended for sale in the ordinary course of business, or use in the process of production for such sale. Consequently, the inventory - it is goods purchased and held for resale, in the broadest sense of the word. If the property or equipment purchased for resale, they are also included in the current reserves and accounted for as goods. Inventories (inventory reserves) are current assets, which can be divided into large groups.

The group includes stocks of raw materials, purchased semi-finished products and components, fuel, containers, spare parts, accessories and housewares (low value items other materials for use in the production process or the performance of work and provision of services.

This group of inventory reserves are reflected on these accounts.

1000 - materials accounting Accounts 1010 "Raw materials" 1020 "Purchased semi-finished products and components" 1030 "Fuel" 1040 "Spare parts" 1050 "Building materials" 1060 "Containers and packing materials" 1070 "Materials transferred for processing to the side "1080" Inventory and household accessories "1090" Other materials "; 1100 accounting accounts animals in growing fattening 1110 "rearers" 1120 "Animals for fattening '; 1500 - Account registration harvested and purchased materials 1510 "Preparation and acquisition of materials"; 1600 - by taking into account variations in the cost of materials: 1610 "Material cost deviation". Similar bills have been prescribed in the old chart of accounts.

Basic principles of accounting of inventory.

1. Inventories are accounted at cost. It should be noted that the estimate for the actual cost is, of course, the basic view of evaluation, but not the only one. Thus, for example, identified in the inventory shortage of values to be measured at their market value; property received free - at market value on the date of posting, etc.

2. Cost of inventories includes all costs of purchase, transport and procurement costs associated with the delivery of inventories to their location and putting in proper condition.
However, according to NAS number 4 acquisition costs of inventories include the purchase price, import duties and taxes, product certification costs, commissions paid to procurement, intermediary organizations, taxes (other than those that the company subsequently receives back in the form of set-off, such as value added tax), as well as transportation and procurement costs and other costs directly attributable to the acquisition of inventories. Trade discounts, rebates and other similar deductions are made when determining the acquisition costs of inventories. Where necessary (at the big nomenclature of the materials used, the intensity of the movement of materials within the company, in agriculture, etc.). You can use the registration materials at discount prices. As used book prices planned cost, average purchase prices, wholesalers and others. When taking into account the materials at discount prices are calculated on a monthly basis and the amount of interest the actual cost of deviations from their value at specified prices. Deviations are recorded in account 1610 "Material cost deviation". Retailers and catering is permitted to assess the acquired goods (products) on the sale price with separate charge into account.

3. At holiday of material assets in the industry (sales of goods) they are evaluated - one of two stock valuation methods: the average cost (avec); on the cost of the first procurement (FIFO); From FIFO method implies that the units of inventory which were purchased first year sold (used) first, and therefore, the units remaining in inventories at the end of the period - the ones that have been made or will take the latter. On a weighted average basis (avec) value of each is determined from the weighted average cost of units of Fashion at the beginning of the period and the cost of similar items purchased or produced during the period. The average may be calculated on a periodic basis or in the course of each additional shipping, depending on the situation prevailing in the economic entity. Use one of the following methods should (be reflected in the accounting policy FIFO method -.. For most businesses is quite a realistic method of reflecting the physical movement of goods from the production or acquisition prior to the sale Where applicable, this method, the cost of inventory is determined according to the latest charges, which actually took place. Thus, this method in most cases leads to an overestimation of the company's profit for the period.

4. Inventories are recorded in the accounts of the account of inventory reserves on the lower of the two estimates - at cost (purchase price or production cost) or market value (not realizable value). Not realizable value - is the estimated selling price of inventories less the value of packaging associated with the completion of production and sales. That is why, the not realizable value - is not the same as the market price of stocks in their present form. It can be 
defined as the actual sales price minus all further costs to completion of the production process, plus any costs as a result of marketing. Not realizable value should be considered for any units or to groups of similar items. It is unacceptable to consider the value of the stock as a whole and then to determine that below - the total cost or net realizable value.

The main situations in which the not realizable value may be less than the value of the stock, are:

- costs rise or fall in the selling price of inventories;
- Wear a physical inventory;

- obsolescence (obsolescence) products;

- the decision to produce and sell products at a loss as part of the company's marketing strategy;

- errors in the production or purchase.

In today's accounting practices of inventory at the enterprises of the Republic of Uzbekistan is the approach to international accounting standards taking into account the peculiarities of the specifics of the enterprises in modern conditions, aimed at efficient use of material resources.

\section{References:}

1. (2015) Nalogovyj kodeks Respubliki Uzbekistan. Tashkent, Adolat, 2015.

2. (2006) Nacional'nyj standart buhgalterskogo ucheta (NSBU) N 4 «Tovarno-material'nye zapasy» (zaregistrirovan Ministerstvom justicii 17.07.2006 g. N 1595)

3. (1998) Nacional'nyj standart buhgalterskogo ucheta (NSBU) N 10 «Uchet gosudarstvennyh subsidij i raskrytie gosudarstvennoj pomoshhi» (zaregistrirovan Ministerstvom justicii 3.12.1998 g. N 562)

4. (2004) Polozhenie $« \mathrm{O}$ dokumentah i dokumentooborote v buhgalterskom uchete» (zaregistrirovano Ministerstvom justicii 14.01.2004 g. N 1297)

5. (1999) Polozhenie o sostave zatrat po proizvodstvu i realizacii produkcii (rabot, uslug) i o porjadke formirovanija finansovyh rezul'tatov (utverzhdeno Postanovleniem Kabineta Ministrov ot 5.02.1999 g. N 54)

6. (2010) Polozhenie o porjadke formirovanija, deklarirovanija (utverzhdenija) i ustanovlenija reguliruemyh cen (tarifov) na tovary (raboty, uslugi) i gosudarstvennogo kontrolja za ih primeneniem (utverzhdeno Postanovleniem Kabineta Ministrov ot 28.10.2010 g. N 239)

7. Breg S (2005) Nastol'naja kniga finansovogo direktora. - Al'pina Pablisher. Moskva, 2005
8. Kondrakov NP (2015) Buhgalterskij (finansovyj, upravlencheskij) uchet. 4-e izdanie. Uchebnik. - Moskva, Prospekt, 2015

9. Ronova GN, Ronova LA (2009) Analiz finansovoj otchetnosti: Uchebno-prakticheskoe posobie //Moskva: Evrazijskij otkrytyj institut. $-2009$

10. Jetrill P (2006) Finansovyj menedzhment //M.: Piter. - 2006

11. Frazelle E, Frazelle E (2002) World-class warehousing and material handling. - New York : McGraw-Hill, 2002. - T. 280

12. Margianti ES, Ikramov MA, Abdullaev AM, Kurpayanidi KI, Ashurov MS (2016) Systematical analysis of the position and further development of Uzbekistan national industry in the case of economic modernization. Monograph. Indonesia, Jakarta, Guandarma Publisher ISBN, 978-602-9438-41-3

13. Kurpayanidi KI (2015) Entrepreneurship in a modern institutional environment. Monograph. Lap Lambert Academic Publishing. Germany 2015. ISBN 978-3-659-71991-2

14. Kurpayanidi K, Muminova E, Paygamov R (2015) Management of innovative activity on industrial corporations. Monograph. Lap Lambert Academic Publishing. Germany 2015. ISBN 978-3-659-76598-8 